\title{
Indirect selection for resistance to Alectra vogelii (benth) infestation in cowpea (Vigna unguiculata (L) walp)
}

\author{
Mbwando. A. ${ }^{1,2}$, Lungu D. $\mathrm{M}^{2}$, Tryphone G. $\mathrm{M}^{3}$, Tembo. L. ${ }^{2}$ \\ ${ }^{1}$ Ilonga Agriculture Research Institute, P. O. Box 33, Kilosa- Morogoro, Tanzania \\ ${ }^{2}$ Department of Plant Science, School of Agricultural Science, University of Zambia, P. O. Box 32347, Lusaka, Zambia \\ ${ }^{3}$ Department of Crop Science and Production, Faculty of Agriculture, Sokoine University of Agriculture, P. O. Box 3005, Chuo \\ Kikuu, Morogoro, Tanzania
}

\begin{abstract}
Alectra vogelii (benth) is a parasitic weed which causes significant yield reductions in cowpeas (Vigna unguiculata Walp) in most of the sub-Saharan African countries. The objective of this study was to establish the effect of Alectra vogelii infestation on yield components of cowpea and the prospects of utilizing these components for indirect select to A. vogelii in resistance breeding. Seven genotypes of cowpea were crossed in all possible combinations without reciprocals and their $21 F_{2}$ progeny including parents were evaluated for reaction to Alectra vogelii infection at two locations, Ilonga and Hombolo. The experiments were laid using a Randomized Complete Block Design with three replications. Significant $(P<0.001)$ genotypic responses to Alectra emergency and infestation were found. A significance negative correlation was found between the Alectra emergency and infestation to yield and yield components $(P<0.01$ and $P<0.001)$. However, both yield components (Number of pods per plant and 100 seed weight) tested exhibited a weak $r^{2}$ value $(<0.25)$ implying that these components can only be used to supplement and not as a substitute to direct selection in breeding for resistance to A. vogelii.
\end{abstract}

Keywords- Alectra vogelii, correlation coefficient, resistance, selection, Vigna unguiculata.

\section{INTRODUCTION}

Cowpea is a most important pulse (legume crop) grown mostly in tropical and subtropical regions in Africa. It is well adapted to various climatic conditions ranging from humid to arid climates and often regarded as drought tolerant legume crop due to its high ability to be grown and giving yield in the areas with little and limited rainfall. Cowpea is grown mainly for human food, animal feeds and fodder, soil fertility improvement, while little of it gets into market as cash crop for income generation to smallholder farmers (Mbwaga et al, 2010; Stanley, 2012). Cowpea is a good source of cheap and high quality protein to many smallholder farmers' households' diet that's merely depends much on cereals crops for their daily diets. Therefore, cowpea in Africa serves as an ideal crop in alleviating the problem of food insecurity, reducing poverty, improving families' nutrition and health condition, and sustaining soil fertility for crop production when grown in intercropping, sole cropping or in rotation with cereals or with other crops (CGIAR, 2012).

Cowpea crop suffers a serious damage from the infestation by a parasitic weed of Alectra vogelii in various part of the sub- Saharan African (Singh and Emechebe, 1997; Mbwaga et al., 2010; Kabambe et al., 2013). Hand weeding, crop rotation, tapping crop and chemical control has been utilized as control strategies to alleviate the damage caused by this parasitic weed in cowpea production though success is very limited (Bouker et al., 2004; Rubiales et al., 2006). Growing of host plant resistance material against of $A$. vogelii infestation has been found to be more effective, environmentally friendly and economically feasible to small scale famers in sub- Saharan Africa (Rubiales et al., 2006). In that effect, genetic studies have been on-going and some materials have been released as a potential source of resistance to A. vogelii (Mbwaga et al., 2010; Karanja et al., 2013; Zitta et al., 2014). It has been reported that resistant genotypes improve yields by improving an effect on one or combination of the yield components such as: minimizing or preventing reduction of number of pods per plant, reduction in pods weight, reduction in number of seeds per pods, reduction in seed weight and reduction in chlorophyll contents of the leaves among other parameters (Geleta, 2010; Omoigui et al., 2011; Kutama et al., 2013; Karanja et 
$a l, 2013)$. Therefore, identifying and quantifying the yield components in cowpea which are affected by A. vogelii infestation could help the breeder understand which component to prioritize when breeding for resistance to $A$. vogelii or could be used as indirect selection criterion in breeding for resistance or tolerance to this parasitic weed of Alectra in cowpea. This is important as screening for $A$. vogelii infestation is dependent on environmental factors (Mainjeni, 1993; Mbwaga et al., 2010). Therefore, the objective of this study was to establish the effect of Alectra vogelii infestation on yield components of cowpea and the prospects of utilizing these components for indirect select to A. vogelii in a breeding program.

\section{MATERIALS AND METHODS}

Experimental layout as well as germplasm used is the same as implemented or utilized by Mbwando et al., 2016 but different evaluation aspects were considered. Field evaluationwere conducted in Ilonga $\left(06^{\circ} \mathrm{S}, 37^{\circ} \mathrm{E}\right.$, Altitude, $506 \mathrm{M}$ ) and Hombolo (5 $52^{\prime} \mathrm{S}, 35^{\circ} \mathrm{E}$, Altitude 1100m) agricultural research stations. Seven cowpea genotypes (Table 1) with varying reaction to Alectra vogelii infestation were assembled from IITA and Ilonga Agriculture Research Institute (ARI- Ilonga). The genotypes were crossed in all possible combinations but without reciprocals to produce 21 $F_{1}$ progeny which were advanced into $F_{2}$ population in the screen house in 2014/2015 cropping season. Rachie et al., 1975 crossing procedures were used for conducting artificial/controlled pollination.

Seven parental genotypes and their $21 \mathrm{~F}_{2}$ crosses were evaluated for their reaction to $A$. vogelii in the field in 2015/2016 cropping season using a randomized complete block design with 3 replications from February to April. Fields assigned for evaluation were naturally infested by Alectra weed, however artificial inoculation was done to increase the pressure of infestation.Infestation of the soil was done by planting Alectra seeds with cowpea seeds at planting time by puttinga full spoon of Alectra seeds per hill that calibrated to deliver about 1000 seeds of

Table.1: Descriptions of materials used in an experiments to determine the reaction of cowpea genotypes to Alectra vogelii infestation in 2014/2015 cropping season at Ilonga and Hombolo Agriculture stations in Tanzania

\begin{tabular}{clll}
\hline Parental identity & Genotype & Reaction to A. vogelii & Source \\
\hline $\mathrm{P}_{1}$ & B301 & Resistant & IITA \\
$\mathrm{P}_{2}$ & IT99K-7-21-2-2-1 & Resistant & ARI-Ilonga \\
$\mathrm{P}_{3}$ & IT99K-573-1 & Resistant & ARI-Ilonga \\
$\mathrm{P}_{4}$ & IT99K-1122 & Tolerant & ARI-Ilonga \\
$\mathrm{P}_{5}$ & VULI-1 & Susceptible & ARI-Ilonga \\
$\mathrm{P}_{6}$ & VULI-2 & Susceptible & ARI-Ilonga \\
$\mathrm{P}_{7}$ & TUMAINI & Susceptible & ARI-Ilonga
\end{tabular}

IITA, International Institute for Tropical Agriculture; ARI, Agricultural Research Institute

Alectra per hill. Single row plot of $5.0 \mathrm{~m}$ length and the spacing between and within row of 0.75 and $0.3 \mathrm{~m}$ respectively were used on sowing cowpea seeds. Trials within two locations were kept free of weeds by hoe weeding for the first five weeks and then by hand weeding from six weeks after planting. No fertilizers were applied to both trials to reduce the interference of $A$. vogelii emergency and infestation.

At 10 weeks after planting data on number of cowpea plants infested by Alectra per plot and number of Alectra shoots emerged per plot were recorded (Geleta, 2010). Number of pods per plot, total grain yield per plot and 100 seed weight were also recordedat crop maturity, 12 weeks after planting. Inspection of the plot of residues (Data not shown) on number of emerged Alectra shoots per plot or number of cowpea plants infested, revealed violation of the ANOVA pre-requirements. Hence data had to be transformed by using square root method, $\sqrt{ }(X+1)$, where " $X$ " was the number of cowpea plants infested by Alectra or number of emerged Alectra shoots per plot to normalized the situation. Genotypic responses among all measured parameters were analyzed using analysis of variances (ANOVA) in GenStat Discovery $15^{\text {th }}$ (Payne et al., 2012). Relationships between parameters measured were equally performed by using correlations ( $r$ ) in GenStat Discovery $15^{\text {th }}$. Amount of Phenotypic evaluation explained $\left(\mathrm{r}^{2}\right)$ was computed as a square of the correlation (r). 


\section{RESULTS AND DISCUSSION}

High significant differences $(\mathrm{P}<0.001)$ were found in all measured parameters among genotypes used in this study at Ilonga site (Table 2) while no significant difference were observed in Alectra emergency and infestation at Hombolo site (Table 3). The observed significance differences among genotypes across the location in their reaction to A. vogelii (Table 4) indicate that the parameters are influenced by environmental changes (Mbwaga et al., 2010).

The mean genotypic responses (Table 5) on measured parameters showed that, Genotype IT99K-573-1xIT99K-7-
21-2-2-1, IT99K-7-21-2-2-1 and IT99K-573-1 were free from Alectra emergency and infestation. VULI-1, IT99K1122xVULI-1 and VULI-1xVULI-2 supported largest number of Alectra shoots and number of cowpea plant infested by Alectra than all genotypes. This result reveals the variations in genotypic responses to some measured traits in this study. Therefore, there is a possibility of utilizing these traits in as an indirect selection criterion in breeding for resistance to Alectra vogelii in cowpea. Total grain yield and number of pods formed per plot exhibited a negative correlation to Alectra shoots emerged and infestation.

Table.2: Analysis of variance mean squares for cowpea genotypes materials used in an experiment to evaluate their reaction to Alectra vogelii infestation at Ilonga site in 2014/2015 cropping season

\begin{tabular}{lclllll}
\hline $\begin{array}{l}\text { Source of } \\
\text { variation }\end{array}$ & d.f & $\begin{array}{c}\text { No. Alectra } \\
\text { Shoots }\end{array}$ & $\begin{array}{l}\text { No. Plant } \\
\text { infested }\end{array}$ & $\begin{array}{l}\text { Grain } \\
\text { Yield }\end{array}$ & $\begin{array}{l}\text { No. Pods } \\
\text { formed }\end{array}$ & $\begin{array}{l}100 \text { seed } \\
\text { weight }\end{array}$ \\
\hline & & & & & & \\
Replication & 2 & 2.13 & 0.56 & 74575 & 51700 & 2.654 \\
Genotypes & 27 & $3.20^{* * *}$ & $0.75^{* * *}$ & $77110^{* * *}$ & $52640^{* * *}$ & $13.84^{* * *}$ \\
Error & 54 & 0.38 & 0.09 & 23411 & 18654 & 2.971 \\
\hline
\end{tabular}

*and $* * *$ significantly different at 0.5 and 0.001 probability levels respectively

Table.3: Analysis of variance mean squares for cowpea genotypes materials used in an experiment to evaluate their reaction to Alectra vogelii infestation at Hombolo site in 2014/2015 cropping season

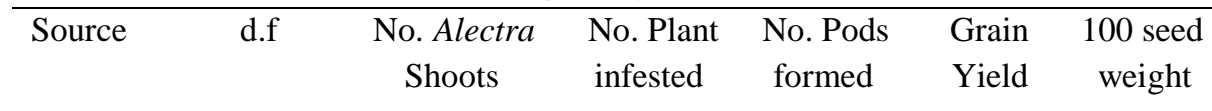

$\begin{array}{lccclll}\text { Replication } & 2 & 0.66 & 0.05 & 11747 & 14993 & 0.8517 \\ \text { Genotypes } & 27 & 1.12 & 0.16 & 27800 * * * & 25799 * * * & 2.90 * * * \\ \text { Error } & 54 & 1.29 & 0.15 & 6446 & 5282 & 0.5942\end{array}$

***, significantly different at 0.001 probability levels

Genotypes where no Alectra shoots emerged, recorded highest number of pods per plot and total grain yield and the reverse was true (Table 5). Karanja et al., (2013) and Zitta et al., (2014) reported the same trend to the response of cowpea genotypes growing under Alectra infestation. This suggests that Alectra infestation probably tends to reduce the yield of cowpea genotypes by allowing the accumulation of dry matter in the cowpea roots at the expenses of the pods so as to feed the parasitic weed of Alectra (Karanja et al., 2013).

Table.4: Analysis of variance mean squares for cowpea genotypes materials used in experiments to evaluate their resistance to Alectra vogelii infestation across sites in 20014/2015 cropping season

\begin{tabular}{lclllll}
\hline Source & d.f & $\begin{array}{c}\text { No. Alectra } \\
\text { Shoots }\end{array}$ & $\begin{array}{c}\text { No. Plant } \\
\text { infested }\end{array}$ & $\begin{array}{l}\text { No. Pods } \\
\text { formed }\end{array}$ & $\begin{array}{l}\text { Grain } \\
\text { Yield }\end{array}$ & $\begin{array}{l}100 \text { seed } \\
\text { weight }\end{array}$ \\
\hline Replication & 2 & 2.51 & 0.38 & 24154 & 30947 & 2.51 \\
Genotypes & 27 & $2.56^{* *}$ & $0.54^{* * *}$ & $59608^{* * *}$ & $79411^{* * *}$ & $13.91^{* * *}$ \\
Location & 1 & 3.59 & $3.57^{* * *}$ & $743071^{* * *}$ & $1364520^{* * * *}$ & $264.86^{* * *}$ \\
G x Location & 27 & 1.77 & $0.37^{*}$ & $20832^{*}$ & $23498^{*}$ & $2.836^{*}$ \\
Error & 54 & 1.20 & 0.15 & 13036 & 15152 & 1.763 \\
\hline
\end{tabular}

$*, * *, * * *$ significantly different at $0.5,0.01$ and 0.001 probability levels respectively 
Mugabe (1983) and Zitta et al., (2014) reported that Alectra infestation causes the reduction in the photosynthetic capability of the plant which results to lower number of pods per plant formed with subsequent reduction in pod weight and total grain yield. This could be due to the reduction in chlorophyll contents of the leaves of the infested cowpea plants due to high competitive nature of the attached parasitic weed on absorbing nutrients crucial for chlorophyll synthesis (Kutama et al., 2013). Likewise, Press (1995) reported that, lower biomass synthesis as a result of competition between the host and parasites for assimilates and solutes, including carbon and water which lowers rate of photosynthesis under Alectra infestation.

Considering these revelations (Press, 2014; Karanja et al., 2013; Zitta et al., 2014) that yield components are directly affected by $A$. Vogelii infestation, there is a need to quantify these correlation responses in order to validate their utilization for indirect selection in breeding for resistance or tolerant to A. vogelii. A significance negative correlation was found between Alectra emergency and infestation to yield component and total yield at Ilonga site (Table 6) while no significant correlation were observed at Hombolo site (Table 7).

Table.5: Response of cowpea genotypes on Alectra shoot emerged, number of cowpea plant infested by Alectra, number of pods formed, 100 seed weight and total grain yield at Ilonga site in 2015 cropping season

\begin{tabular}{|c|c|c|c|c|c|}
\hline $\begin{array}{l}\text { Genotype/ } \\
\text { Crosses }\end{array}$ & $\begin{array}{l}\text { No of Alectra } \\
\text { Shoot/ plot }\end{array}$ & $\begin{array}{l}\text { No of Cowpea Plant } \\
\text { Infested/ plot }\end{array}$ & $\begin{array}{l}\text { No of Pods } \\
\text { Formed }\end{array}$ & $\begin{array}{l}100 \text { Seed } \\
\text { Weight }\end{array}$ & $\begin{array}{l}\text { Total Grain } \\
\text { Yield/ plot }\end{array}$ \\
\hline $\mathrm{P}_{3} \mathrm{XP}_{4}$ & 0.00 & 0.00 & 664.0 & 10.19 & 809.0 \\
\hline $\mathrm{P}_{2}$ & 0.00 & 0.00 & 706.3 & 9.64 & 893.0 \\
\hline $\mathrm{P}_{3}$ & 0.00 & 0.00 & 458.0 & 11.83 & 655.3 \\
\hline $\mathrm{P}_{4}$ & 0.33 & 0.33 & 586.3 & 8.94 & 769.1 \\
\hline $\mathrm{P}_{2} \mathrm{XP}_{7}$ & 1.00 & 0.67 & 504.3 & 11.19 & 614.6 \\
\hline $\mathrm{P}_{1}$ & 1.33 & 0.67 & 438.0 & 11.15 & 558.7 \\
\hline $\mathrm{P}_{1} \mathrm{XP}_{4}$ & 1.67 & 1.67 & 482.0 & 12.08 & 530.3 \\
\hline $\mathrm{P}_{5} \mathrm{xP}_{7}$ & 1.67 & 1.33 & 343.0 & 17.59 & 437.4 \\
\hline $\mathrm{P}_{2} \mathrm{XP}_{4}$ & 2.33 & 1.00 & 506.3 & 9.64 & 608.5 \\
\hline $\mathrm{P}_{2} \mathrm{XP}_{5}$ & 2.33 & 1.33 & 402.0 & 11.94 & 509.0 \\
\hline $\mathrm{P}_{1} \mathrm{xP}_{2}$ & 2.67 & 2.00 & 312.7 & 12.02 & 433.4 \\
\hline $\mathrm{P}_{2} \mathrm{XP}_{3}$ & 2.67 & 2.00 & 443.3 & 11.51 & 536.3 \\
\hline $\mathrm{P}_{3} \mathrm{XP}_{5}$ & 2.67 & 1.33 & 377.7 & 12.26 & 480.8 \\
\hline $\mathrm{P}_{4} \mathrm{XP}_{5}$ & 2.67 & 2.33 & 397.0 & 11.60 & 498.8 \\
\hline $\mathrm{P}_{2} \mathrm{XP}_{6}$ & 2.67 & 1.33 & 378.0 & 11.41 & 475.1 \\
\hline $\mathrm{P}_{1} \times \mathrm{P}_{5}$ & 3.00 & 2.67 & 437.3 & 10.80 & 508.1 \\
\hline $\mathrm{P}_{1} \times \mathrm{P}_{7}$ & 4.00 & 1.67 & 440.3 & 9.81 & 522.2 \\
\hline $\mathrm{P}_{3} \mathrm{XP}_{7}$ & 4.00 & 1.33 & 358.7 & 12.91 & 410.5 \\
\hline $\mathrm{P}_{1} \mathrm{XP}_{3}$ & 5.00 & 2.00 & 245.3 & 13.97 & 249.0 \\
\hline $\mathrm{P}_{3} \mathrm{XP}_{6}$ & 6.00 & 1.33 & 557.3 & 11.15 & 593.5 \\
\hline $\mathrm{P}_{6}$ & 6.33 & 3.00 & 382.3 & 9.50 & 427.4 \\
\hline $\mathrm{P}_{1} \mathrm{xP}_{6}$ & 6.67 & 2.67 & 343.0 & 17.59 & 436.4 \\
\hline $\mathrm{P}_{7}$ & 7.67 & 3.00 & 338.0 & 10.86 & 381.0 \\
\hline $\mathrm{P}_{4} \mathrm{XP}_{7}$ & 8.00 & 3.00 & 97.9 & 14.0 & 158.5 \\
\hline $\mathrm{P}_{6} \mathrm{XP}_{7}$ & 13.67 & 5.00 & 103.0 & 15.1 & 93.1 \\
\hline $\mathrm{P}_{5}$ & 14.33 & 4.67 & 304.7 & 13.04 & 301.2 \\
\hline $\mathrm{P}_{4} \times \mathrm{XP}_{6}$ & 19.67 & 6.33 & 271.0 & 12.59 & 292.6 \\
\hline $\mathrm{P}_{5} \mathrm{xP}_{6}$ & 29.00 & 8.67 & 190.0 & 13.54 & 276.6 \\
\hline L.S.D & 11.15 & 3.14 & 223.6 & 2.82 & 250.5 \\
\hline
\end{tabular}

LSD- Least Significant difference performed at 5\% level of probability 
The fact that no significant correlations for yield components to 'A vogelii infestation' and 'number of Alectra emerged' were obtained at Hombolo, implies that the significant correlations observed in Ilonga are directly linked to the effect of $A$. vogelii on cowpea genotypes. Thus unlike in Hombolo significant genotypic responses among traits measured to Alectra infestation were obtained at Ilonga. Failure to obtain significant differences in Hombolo on genotypic responses to $A$. vogelii could be due to environmental factors of which drought is a suspect. This is supported by Mbwaga et al., 2010 who deduced that drought reduces the virulent effect of $A$. vogelii. Indeed in this season Hombolo received $437.82 \mathrm{~mm}$ amount of rainfall compared to Ilonga which received $1002.64 \mathrm{~mm}$. Total grain yield had highly significant $(\mathrm{P}<0.001)$ negative correlation coefficients with both number of Alectra shoots emerged and number of cowpea plant infested $(r=-0.39$ and $r=-0.46$ respectively). Likewise number of pods per plot also had a highly significant $(\mathrm{P}<0.001)$ negative correlation coefficient with both number of Alectra shoots emerged and number of cowpea plant infested $(r=-0.37$ and $\mathrm{r}=-0.44$ respectively). On the other hand, hundred seed weight also was found to have a significant $(\mathrm{P}<0.01)$ negative correlation coefficient with both number of Alectra shoots emerged and number of cowpea plant infested $(r=-$ 0.26 and $r=-0.33$ respectively). These results suggested that, there were a decrease in number of pods per plant formed, seed weight (100 seeds weight) and total grain yields in the cowpea plant with increasing in number of $A$. vogelii shoots emerged. This signifies that, there is high competition for assimilates and solutes between cowpea plant and Alectra and probably most of the assimilates synthesized by the crop are deposited in the roots of cowpea at the expenses of the pods so as to feed the parasitic weeds of Alectra vogelii which leads to the reduction of the total grain yields of the crop (Press, 1995; Karanja et al., 2013). The significance negative correlation between seed weight to number of Alectra shoots emerged and number of cowpea plants infested by Alectra suggested that, Alectra reduces the quality of seed by affecting seed size (Mbwaga et al., 2007 and 2010; Karanja et al., 2013).

Total grain yield had recorded a positive significant $(\mathrm{P}<$ 0.001 and $\mathrm{P}<0.05)$ correlation with number of pods per plot $(\mathrm{r}=0.94)$, while negative significant $(\mathrm{P}<0.01)$ correlation was observed with correlation 100 seed weight $(\mathrm{r}=-0.29)$ (Table 6). The positive and significance correlation between total grain yield and number of pods per plot suggested that yield improvement would be possibly be achieved by selecting for the number of pods per plant. However, number of pods is also negatively correlated with Alectra infestation and this signifying that yield improvement under Alectra vogelii infestation would be enhanced by indirectly selecting for plants with higher number of pods per plant. However the low $r^{2}\left(r^{2}=0.07\right)$, (which is a measure of the amount of phenotypic variation explained) imply that number of pods cannot be used as a solely selection criterion but can be used to supplement direct selection methods.

Table.6: Correlation coefficient among yield, yield components, number of Alectra shoots emerged and number of cowpea plants infested by Alectra for cowpea genotypes materials used in an experiment to evaluate their reaction to Alectra vogelii infestation at Ilonga site in 2014/2015 cropping season

\begin{tabular}{|c|c|c|c|c|c|}
\hline & $\begin{array}{l}\text { No of Cowpea Plant } \\
\text { infested by Alectra }\end{array}$ & $\begin{array}{l}\text { No of Alectra } \\
\text { shoot emerged }\end{array}$ & $\begin{array}{c}100 \text { seed } \\
\text { weight }\end{array}$ & $\begin{array}{l}\text { No of Pods } \\
\text { formed }\end{array}$ & $\begin{array}{l}\text { Total Grain } \\
\text { Yield }\end{array}$ \\
\hline \multicolumn{6}{|l|}{ No of Cowpea Plant infested } \\
\hline No of Alectra shoot emerged & $0.8773 * * *$ & & & & \\
\hline 100 Seed Weight & $-0.3256^{* *}$ & $-0.2545^{* *}$ & & & \\
\hline No of Pods formed & $-0.4415 * * *$ & $-0.3705^{* * *}$ & $-0.3314 * *$ & & \\
\hline Total Grain Yield & $-0.4595 * * *$ & $-0.3920 * * *$ & $-0.2947 * *$ & $0.9442 * * *$ & ----- \\
\hline
\end{tabular}
$* *, * * *$ significantly different at 0.01 , and 0.001 probability levels respectively 
Table.7: Correlation coefficient among yield, yield components, number of Alectra shoots emerged and number of cowpea plants infested by Alectra for cowpea genotypes materials used in an experiment to evaluate their reaction to Alectra vogelii infestation at Hombolo site in 2014/2015 cropping season

$\begin{array}{ccccc}\begin{array}{c}\text { No of cowpea plant } \\ \text { infested by Alectra }\end{array} & \begin{array}{c}\text { No of Alectra } \\ \text { shoot emerged }\end{array} & \begin{array}{c}100 \text { seed } \\ \text { Weight }\end{array} & \begin{array}{c}\text { No of Pods Total Grain } \\ \text { formed }\end{array} & \text { Yield }\end{array}$

\begin{tabular}{lcccc}
\hline No of Cowpea Plant infested & & & & \\
No of Alectra shoot emerged & $0.8320^{* * *}$ & & & \\
100 Seed Weight & -0.0810 & -0.1118 & & \\
No of Pods formed & -0.0613 & -0.0028 & -0.0918 & \\
Total Grain Yield & -0.0834 & -0.0302 & -0.1823 & $0.9602^{* * *}$ \\
\hline
\end{tabular}
*** significantly different at 0.001 probability level

\section{CONCLUSION}

Results showed that among the yield components tested, $A$. vogelii infestation (in Ilonga where significant genotypic responses were obtained) affected number of pods per plant $\left(r=-0.44 ; r^{2}=0.19\right)$ much more than seed weight $(r=-0.33$; $\left.r^{2}=0.11\right)$. However both components showed low $r^{2}$ values implying that these components especially number of pods per plant (since it's positively correlated to yield) can only be used to supplement and not as a substitute to direct selection in breeding for resistance to A. vogelii in cowpea.

\section{ACKNOWLEDGEMENT}

I am very grateful to Innovative Agricultural Research Initiative (iAGRI) project in Tanzania for supporting this research as part of Masters study at the University of Zambia through association with Regional Universities Forum for Capacity Building in Agriculture (RUFORUM). Also am grateful to McKnight Foundation Collaborative Crops Research Project in Tanzania to their financial support for the publication of this article.

\section{REFERENCES}

[1] Acquaah, G. 2007. Introduction to quantitative genetics In: Principles of plant genetics and breeding. Black well Publisher, Carlton Australia. pp 126-144.

[2] AOAC. 1984. Official methods of analysis. 14 ${ }^{\text {th }}$, Association of Official Analytical Chemists. Washington, DC, USA: 522-533.

[3] Boukar, O., Kong, L., Singh, B. B., Murdock, L and Ohm, H. W. 2004. AFLP and AFLP-derived SCAR markers associated with Striga gesnerioides resistance in cowpea. Journal of Crop Science, 44: 1259-1264.
[4] Geleta, L. F. 2010. Cowpea landraces of Botswana: A potential resistance source for Alectra vogelii. Aspect of Applied Biology: pp 96.

[5] CGIAR. 2012. Leveraging legumes to combat poverty, hunger, malnutrition and environmental degradation. In: Research program on grain legumes. Unpublished revised proposal submitted by ICRISAT, CIAT, ICARDA and IITA to CGIAR 15 August, 2012: 7-12

[6] Kabambe, V., Katanga, L., Kapewa, T., Ngwira, A. R. 2008. Screening legumes for integrated management of witch weeds (Alectra vogelii and Striga asiatica) in Malawi. AfricanJournal of Agricultural Research, 3: 708-715.

[7] Karanja, J. K., Nguluu, S. N., Wambua, J., Gatheru, M. 2013. Response of cowpea genotype to Alectra vogelii parasitism in Kenya. African Journal of Biotechnology, 12: 6591-6598.

[8] Karanja, J. K., Nguluu, S. N., Gatheru, M. 2010. Farm yard manure reduces the virulence of Alectra vogelii (Benth) on cowpea (Vigna unguiculata). Unpublished paper presented at Bondo University College conference, February, 2010.

[9] Kutama A. S., Hayatu, M., Umar, S. 2013. Effect of Alectra vogelii (Benth) Infestation on the Growth of some Genotypes of Cowpea (Vigna unguiculata [L] Walp). Standard Research Journal of Agricultural Science, 2: 33- 39.

[10] Mbwaga, A., Hella, J., Mligo, J., Kabambe, V., Bokos, J. 2007. Development and promotion of Alectra resistant cowpea cultivars for smallholder farmers in Malawi and Tanzania. McKnight Foundation Collaborative Crops Research Project No: 06741.

[11] Mbwaga, A., Hella, J., Mligo, J., Kabambe, V., Bokos, J. 2010. Development and promotion of Alectra 
resistant cowpea cultivars for smallholder farmers in

Malawi and Tanzania. McKnight Foundation

Collaborative Crops Research ProjectNo: 06741.

[12] Mbwando A., Lungu, D. M., Tryphone, G. M., Tembo, L. 2016. Nature of resistance of cowpea Alectra vogelii infestation. African Crop Science Journal. 24: 389-395.

[13] Omoigui, L. O., Kamara. A. Y., Ishiyaku, M. F., Bouker, O. 2012. Comparative response of cowpea breeding lines to Striga and Alectra in the dry savannah of northeast Nigeria. African Journal of Agricultural Research, 13:45-67.

[14] Press, M. C. 1995. How do the parasitic weeds Striga and Orobancheae influence host carbon relation? Aspects of Applied Biology, 42: 63-70.

[15] Payne, R. W., Murray, D. A., Harding, S. A., Baird, D. B., Soutar, D. M. 2012. An Introduction to GenStat for Windows $\left(17^{\text {th }}\right.$ Edition). VSN International, Hemel Hempstead, UK

[16] Rubiales, D., Perez de Luque, A., Fernandez-Aparica, M., Sillero, J. C., Roman, B., Kharrat, M., Khalil, S., Joel, D. M., Riches, C. R (2006) Screening techniques and sources of resistance to parasitic weeds in grain legumes. Euphytica, 147: 187-199.

[17] Rugare, J. T., Mbwasa, S., Tsekenedza, S. 2013. Response of Cowpea (Vigna unguiculata L.) Genotypes to Witch weed Alectra vogelii (Benth) Infection. Asian Journal of Agricultural and Rural Development, 3: 667-673.

[18] Simmonds, N. W. 1979. Principles of crop improvement, Longman Inc. New York, United states of America:95-97

[19] Singh, B. B., Emechebe, A. M. 1997. Advances in research on cowpea Striga and Alectra. In: Advances in cowpea research. Singh, B.B., Mohan, R., Dashiell, K.E and Jackai, L.E.N:215-224. IITA-Jirca, Ibadan, Nigeria.

[20] Zitta, C., Magani, E. I., Ahom, R. I. 2014. Screening of Cowpea Genotypes for their Reaction to Alectra vogelii (Benth) in the Southern Guinea Savanah of Nigeria. Journal of Natural Science Research: 14- 15. 